\begin{tabular}{l|l} 
Jurnal Eksplorasi Akuntansi & $\begin{array}{l}\text { Vol. 2, No. 1, Seri D, Februari 2020, Hal 2428-2444 } \\
\text { ISSN : 2656-3649 (Online) } \\
\text { http://jea.ppj.unp.ac.id/index.php/jea/issue/view/20 }\end{array}$
\end{tabular}

\title{
PENGARUH PROFITABILITAS, LEVERAGE, DAN KOMPOSISI DEWAN KOMISARIS INDEPENDEN TERHADAP PENGUNGKAPAN CORPORATE SOCIAL RESPONSIBILITY
}

\section{(Studi Empiris pada Perusahan Pertambangan yang Terdaftar di Bursa Efek Indonesia pada Tahun 2014-2018)}

\author{
Fitri Herdi', Erinos NR ${ }^{2}$ \\ ${ }^{1}$ Alumni Jurusan Akuntansi Fakultas Ekonomi Universitas Negeri Padang \\ ${ }^{2}$ Jurusan Akuntansi Fakultas Ekonomi Universitas Negeri Padang \\ *Korespondensi: fitrihendri231@gmail.com
}

\begin{abstract}
This study aims to determine the effect of profitability, leverage, and the composition of the independent board of commissioners on the disclosure of corporate social responsibility. The population in this study were mining companies listed on the Indonesia stock Exchange (IDX) in 2014 to 2018. The research sample was determined using a purposive sampling method, and a total sample of 10 mining companies. The data used is secondary data. Data collection techniques with documentation at www.idx.co.id. The analytical method used is Moderated Regression Analysis. The results showed that profitability had a positive and not significant effect on CSR, leverage had a negative and not significant effect on CSR, and the composition of the independen board of commissioners had a negative and not significant effect on CSR..
\end{abstract}

Keywords: Composition of The Independent Board Of Commisssioers, Corporate Social Responsibility, Leverage, Profitbilitas

How to cite (APA $6^{\text {th }}$ style):

Herdi, Fitri., \& NR, Erinos. (2020). Pengaruh Profitabilitas, Leverage, dan Komposisi Dewan Komisaris Independen Terhadap Pengungkapan Corporate Social Responsibility (Studi Empiris pada Perusahaan Pertambangan yang Terdaftar di Bursa Efek Indonesia Periode 2014-2018). Jurnal Eksplorasi Akuntansi. 2(1), Seri D, 2428-2444.

\section{PENDAHULUAN}

Corporate Social Responsibility (CSR) adalah tindakan yang dilakukan oleh perusahaan sebagai rasa tanggung jawab terhadap lingkungan yang berdampak dari operasi perusahaan sehingga meningkatkan kualitas hidup dari kualitas yang kurang baik (Darwin, 2006). Pengungkapan corporate social responsibility menjadi topik yang diperbincangkan di Indonesia, Kepedulian masyarakat semakin besar terhadap pentingnya tanggung jawab sosial perusahaan. Perkembangan CSR terkait dengan semakin parahnya kerusakan lingkungan yang terjadi di Indonesia maupun dunia, mulai dari pencemaran udara, tanah, air, eksploitasi sumber daya alam dan tenaga kerja yang pada akhirnya mengganggu kelangsungan hidup manusia, ini semua sangat perlu dilakukan pengungkapan. 
Pengungkapan tanggung jawab sosial perusahaan di Indonesia bukan lagi bersifat sukarela melainkan termasuk pengungkapan wajib (mandatory disclosre) karena telah diatur dalam peraturan Undang-Undang RI No.40 tahun 2007 tentang perseroan terbatas, namun bentuk laporan CSR masih sangat bervariatif karena belum ada aturan resmi dalam menyajikan kegiatan CSR. Undang-undang memang telah diatur oleh pemerintah, namun demikian penetapan undang-undang tersebut tidak membuat pelaporan lingkungan bebas dari kelemahan/keterbatasan, sehingga masih ada perusahaan yang mengabaikan lingkungan sekitar, penebangan pohon, dan pembuangan limbah perusahaan yang berdampak pada lingkungan masyarakat itu sendiri (Sary, 2014).

Perusahaan dapat bekerja dan memperoleh keuntungan jika bisa memposisikan diri dalam lingkungan bisnis dan lingkungan sosialnya. Lingkungan bisnis dan lingkungan sosial mempunyai kaitan sehingga tidak mungkin suatu perusahaan mencapai kerja yang efektif apabila mengabaikan lingkungan sosialnya. Aktivitas perusahaan menimbulkan masalah sosial dan lingkungan, maka sudah seharusnya entitas bisnis bersedia untuk menyajikan suatu laporan yang dapat mengungkapkan bagaimana kontribusi perusahaan terhadap berbagai permasalahan sosial yang terjadi disekitarnya.

Informasi yang sering diminta untuk diungkapkan perusahaan saat ini adalah informasi tentang tanggung jawab sosial perusahaan. Tanggung jawab sosial perusahaan itu sendiri dapat digambarkan sebagai ketersedian informasi keuangan dan non-keuangan berkaitan dengan interakasi organisasi dengan lingkungan fisik dan lingkungan sosialnya, yang dapat dibuat dalam laporan tahunan perusahaan atau laporan sosial terpisah Guthrie dan Mathews (1985) dalam sembiring (2005).

Permasalahan di Indonesia mengenai pengungkapan corporate social responsibility telah diteliti dan di analisis oleh beberapa peneliti. Diantaranya riset Oktavila dan Erinos (2019) pada perusahaan manufaktur di Indonesia periode 2015-2017 menemukan bukti empiris bahwa kapitalisasi pasar, kepemilikan institusional, komite audit dan ukuran dewan komisaris berpengaruh signifikan terhadap pengungkapan Corporate Social Responsibility. Riset Rachman dan Nopiyanti (2015) serta Krisna dan Suhardianto (2016) CSR dipengaruhi oleh profitabilitas, leverage, dan ukuran perusahaan. Penelitian Krisna dan Suhardianto (2016) yang mana terdapat penambahan variabel yaitu dewan komisaris, serta dewan direksi, penelitian ini menunjukkan hasil yang hampir sama hanya saja terdapat sedikit perbedaan pada variabel komite audit dan ukruan perusahaan menunjukkan pengaruh signifikan secara positif terhadap pengungkapan CSR.

Profitabilitas diprediksi sebagai salah satu variabel yang mempengaruhi pengungkapan tanggung jawab sosial perusahaan. Profitabilitas suatu perusahaan menunjukkan perbandingan antara laba dengan aktiva atau modal yang menghasilkan laba tersebut. Menurut Yusra (2009), profitabilitas memberikan kebebasan dan fleksibilitas kepada manajemen untuk mengungkapkan pertanggungjawaban sosial kepada pemegang saham. Pengungkapan informasi sosialnya juga semakin besar apabila tingkat profitabilitas semakin tinggi. Hasil penelitian Rindawati \& Asyik (2015) mengatakan bahwa profitabilitas berpengaruh positif dan signifikan terhadap pengungkapan CSR Terdapat perbedaan dengan penelitian Krisna \& Suhardianto (2016) yang menyatakan bahwa profitabilitas tidak berpengaruh secara positif dan tidak signifikan terhadap pengungkapan CSR.

Leverage merupakan kemampuan suatu perusahaan memenuhi kewajiban jangka panjangnya dan memberikan gambaran mengenai struktur modal yang dimiliki perusahaan, sehingga dapat dilihat tingkat resiko tak tertagihnya suatu utang. Hasil penelitian Oktaviana dan Rustianingsih (2013) menyatakan bahwa leverage berpengaruh positif dan tidak signifikan, 
sedangkan penelitian Robiah dan Erawati (2017) yang menyatakan bahwa leverage tidak berpengaruh positif dan tidak signifikan dan tidak signifikan terhadap pengungkapan CSR.

Faktor lain yang diperkirakan berpengaruh terhadap pengungkapan CSR adalah komposisi dewan komisaris independen ini berkaitan dengan pengelolaan perusahaan yang dilaksanakan oleh manajemen dan mendorong perusahaan untuk mengungkapkan laporan csr. Penelitian Nur dan Priantinah (2012) menyatakan komposisi dewan komisaris independen berpengaruh secara negatif dan signifikan, terdapat perbedaan dengan penelitian Komalasari et al (2014) menyatakan komposisi dewan komisaris independen tidak berpengaruh posiitf dan tidak signifikan terhadap pengungkapan CSR.

Fenomena yang terkait dengan pengungkapan tanggung jawab sosial di Indonesia seperti pada PT. Freeport, PT. Unocal dan masih banyak lagi yang lainnya. Pembuangan limbah tambang yang tidak diolah kembali akibat dari operasi perusahaan. Penelitian ini merupakan replikasi dari penelitian yang dilakukan oleh Rachman dan Nopiyanti (2015) dengan menambah variabel baru yaitu komposisi dewan komisaris independen.

Berdasarkan latar belakang masalah yang telah dijelaskan sebelumnya, maka peneliti tertarik untuk melakukan penelitian mengenai corporate social responsibility dengan mengambil judul "Pengaruh profitabilitas, leverage, dan komposisi dewan komisaris terhadap corporate social responsibility" (Studi Empiris Pada Perusahaan Pertambangan yang Terdaftar di Bursa Efek Indonesia Tahun 2014-2018)”.

\section{REVIU LITERATUR DAN PENGEMBANGAN HIPOTESIS Teori Legitimasi}

Teori legitimasi merupakan hubungan simbosis mutualisme yang mana diharapkan suatu kegiatan tersebut saling menguntungkan diantara pihak satu dengan pihak lain. Legitimasi masyarakat dapat dijadikan sebagai faktor strategis bagi perusahaan dalam rangka mengembangkan perusahaan ke depan (Hadi, 2011:87). Legitimasi adalah keadaan mengenai psikologis keberpihakan seseorang mengenai kepekaan terhadap gejala lingkungan sekitarnya baik fisik maupun non fisik.

Teori legitimasi adalah salah satu teori yang mendasari pengungkapan CSR. Upaya mendapatkan nilai positif dan legitimasi dari masyarakat maka pengungkapan tanggung jawab sosial perusahan harus dilakukan. Teori legitimasi juga dapat digunakan untuk menjelaskan keterkaitan profitabilitas, dengan profitabilitas yang mencukupi akan mendapatkan legitimasi dari masyarakat yang pada akhirnya akan berdampak meningkatkan keuntungan perusahaan di masa yang akan datang (Nurkhin, 2009).

\section{Teori Stakeholders}

Perusahaan yang beroperasi tidak hanya sekedar bertanggung jawab terhadap para pemilik (shareholder) sebagaimana terjadi selama ini, namun bergeser menjadi luas yaitu sampai pada ranah sosial (social responsibility). Fenomena seperti ini terjadi, karena adanya dari masyarakat akibat negative externalities yang timbul serta ketimpangan sosial yang terjadi (Hadi, 2011:93).

Perusahaan bukan tidak mungkin akan menuai protes dan dapat mengeliminasi legitimasi stakeholder apabila perusahaan tidak memperhatikan stakeholder, karena perusahaan tidak akan bisa terlepas dari hubungan lingkungan sosial (social setting) sekitarnya. Perusahaan berupaya untuk menjaga reputasinya dengan menggeser pola erientasi (tujuan) yang semula semata-mata diukur dengan economic measurement yang cenderung shareholder orientation, kearah 
memperhitungkan faktor sosial (social factors) sebagai wujud kepedulian dan keberpihakan terhadap masalah sosial kemasyarkaatan (stakeholder orientation) (Hadi, 2011:95).

\section{Teori Keagenan}

Teori keagenan merupakan adanya hubungan kontrak antara principal dan agen, dimana principal adalah pihak yang mempekerjakan agent agar melakukan tugas untuk kepentingan principal, menjelaskan sebuah hubungan yang didalamnya terjadi kontrak atau perjanjian antara satu pihak, yaitu pemangku kepentingan (kreditor), dengan pihak lain yaitu perusahaan. Teori keagenanan adalah pemberian wewenang oleh pemilik perusahaan (pemegang saham) kepada pihak manajemen perusahaan untuk menjalankan operasional perusahaan sesuai dengan kontrak yang telah disepakati, jika kedua belah pihak memiliki kepentingan yang sama untuk meningkatkan nilai perusahaaan maka manajemen akan bertindak sesuai dnega kepentingan pemilik perusahaan (Scott, 2003).

Perusahaan memerlukan biaya dalam dalam rangka untuk memberikan informasi pertanggungjawaban sosial, sehingga laba yang dilaporkan dalam tahun berjalan menjadi lebih rendah. Ketika perusahaan menghadapi biaya kontrak dan biaya pengawasan yang rendah dan vasibilitas politis yang akan cenderung untuk mengungkapkan infromasi pertanggungjawaban sosial (Anggraini, 2006).

\section{Corporate Social Responsibility}

Menurut Untung (2014:1) CSR adalah bentuk tanggung jawab perusahaan terhadap lingkungannya bagi kepedulian sosial maupun tanggung jawab lingkungan dengan tidak mengabaikan kemampuan dari perusahaan. Perusahaan dalam melaksanakan aktivitasnya harus berdasarkan keputusannya tidak hanya berdasarkan faktor keuangan belaka seperti halnya keuntungan atau dividen, melainkan juga harus berdasarkan konsekuensi sosial di lingkungan untuk saat ini maupun jangka panjang.

Pergerakan Industrial berdampak negative terhadap lingkungan dan pranata sosial sekitarnya yang membutuhkan mobilisasi sumber daya sehingga kecil ataupun besar, cepat maupun lambat dapat mengganggu keseimbangan sumber daya tersebut. Pentingnya pembagian tanggung jawab perusahaan terhadap lingkungan dan masyarakat, agar terjadi keseimbangan eksploitasi (Hadi, 2011:45). Menurut (Zadex 1998 dalam Sembiring 2005), alasan perusahaan melakukan pengungkapan tanggung jawab sosial yaitu untuk memahami apakah perusahaan telah mencoba mencapai kinerja sosial terbaik sesuai yang diharapkan, mengetahui apa yang dilakukan perusahaan dalam meningkatkan kinerja sosial, untuk memahami implikasi dari apa yang dilakukan perusahaan tersebut.

\section{Profitabilitas}

Profitabilitas menunjukkan kemampuan perusahaan memperoleh laba yang mempunyai hubungan dengan penjualan, total aktiba, dan ekuitas. Profitabilitas berguna dalam upaya mempertahankan kelangsungan hidup perusahaan dalam jangka panjang, karena profitabilitas memperlihatkan apakah entitas tersebut mempunyai prospek yang baik di masa yang akan datang ataukah tidak. Rasio profitabilitas menurut Kasmir (2008) merupakan rasio untuk menilai kemampuan perusahaan dalam mencari keuntungan. Jenis profitabilitas yang sering dipakai untuk meninjau kemampuan perusahaan dalam menghasilkan laba yaitu net profit margin, return on investment, return on equity. 


\section{Leverage}

Leverage adalah alat yang digunakan untuk mengukur seberapa besar perusahaan memiliki tingkat resiko hutang tak tertagihnya pada kreditur yang nantinya akan digunakan dalam membiayai aset perusahaan. Teori keagenan memprediksi Perusahaan yang mempunyai tingkat leverage tinggi berarti sangat berpengaruh pada pinjaman luar untuk membiayai asetnya, dan sabaliknya perusahaan yang mempunyai tingkat leverage lebih rendah lebih banyak membiayai assetnya dengan modal sendiri. Menurut Febrina dan Suaryana (2011) perusahaan yang beresiko tinggi berusaha meyakinkan kreditur dengan pengungkapan informasi yang lebih detail. Tambahan informasi sangat diperlukan untuk menghilangkan keraguan terhadap terpenuhinya hak-hak para kreditur.

\section{Komposisi Dewan Komisaris Independen}

Merupakan bagian puncak dari sistem pengelolaan internal perusahaan yang memiliki peran terhadap aktivitas perusahaan (Nurkhin, 2009). Dewan komisaris bertugas dan mempunyai tanggung jawab untuk melaksanakan pengawasan dan memberikan nasihat kepada direksi serta memastikan bahwa perusahaan telah melaksanakan good corporate governence serta sesuai aturan yang berlaku. Pengambilan keputusan operasional dewan komisaris tidak diperbolehkan turut serta, dewan komisaris terbagi dari komisaris yang tidak berasal dari pihak terafiliasi yang disebut sebagai komisaris independen yang terafiliasi.

Keberadaan komisaris independen telah diatur sejak 1 juli 2000 oleh Bursa Efek Jakarta melalui peraturan BEJ. Peraturan tersebut menyatakan bahwa perusahaan yang listed di bursa harus memiliki komisaris independen yang secara proporsional sama dengan jumlah saham yang dimiliki pemegang saham minoritas. Peraturan tersebut juga mengatur mengenai jumlah minimal komisaris independen yaitu 30\% dari keseluruhan anggota komisaris.

\section{Pengaruh Profitabilitas Terhadap Corporate Social Responsibility}

Perusahaan yang memiliki kondisi keuangan yang kuat, juga akan mendapatkan tekanan yang lebih dari pihak eksternal perusahaan untuk lebih mengungkapkan pertanggungjawaban sosialnya secara luas. Perusahaan yang memiliki keuntungan lebih besar harus lebih aktif melaksanakan CSR (Amran dan Devi, 2008).

Menurut Evi et al (2011) Pemegang saham tidak hanya menginginkan informasi mengenai pendapatan suatu perusahaan yang mengalami kenaikan atau penurunan. Informasi lain yang dibutuhkan para pemegang saham mengenai informasi sejauh mana perusahaan dapat menggunakan pendapatan yang dimiliki untuk membiayai kegiatan operasional perusahaan, baik dari internal maupun eksternal perusahaan. Terdapat kaitan dengan informasi yang dibutuhkan oleh para pemegang saham, salah satu kegiatan eksternal yang dilaksanakan perusahaan adalah mengenai aktivitas sosial yang mampu dilakukan perusahaan selama perusahaan tersebut beroperasi. Berdasarkan penjelasan tersebut dapat ditarik hipotesis, yaitu : $\mathrm{H}_{1}$ : Profitabilitas berpengaruh positif terhadap corporate social responsibility.

\section{Pengaruh Leverage Terhadap Corporate Social Responsibility}

Teori keagenan menjelaskan bahwa perusahaan dengan rasio leverage yang lebih tinggi akan mengungkapkan lebih banyak informasi, karena biaya keagenan seperti itu lebih tinggi. Perusahaan besar akan lebih cenderung memiliki aktivitas yang lebih banyak dan membutuhkan biaya yang lebih banyak informasi, sehingga hal ini membuat perusahaan membutuhkan dana untuk kegiatan operasionalnya. Perusahaan yang memiliki tingkat leverage lebih tinggi memiliki 
kewajiban untuk melakukan pengungkapan yang lebih banyak salah satunya adalah dengan mengungkapkan CSR. Pengungkapan yang semakin luas membuat pihak kreditor semakin banyak memperoleh informasi. Upaya yang dilakukan bertujuan agar investor dapat memperoleh keyakinan atas terjaminnya hak mereka sebagai kreditur (Anugerah, Rolland dan Faradilla, 2010). Jadi, berdasarkan penjelasan tersebut dapat ditarik hipoteisi, yaitu:

$\mathrm{H}_{2}$ : Leverage berpengaruh positif terhadap corporate social responsibility.

\section{Pengaruh Komposisi Dewan Komisaris Independen Terhadap Corporate Social Responsibility}

Secara umum dewan komisaris independen dalam mekanisme GCG berperan penting tidak hanya melihat kepentingan pemilik tetapi juga kepentingan perusahaan secara umum. Komisaris independen adalah pihak yang tidak dapat dipengaruhi oleh pihak lain karena komisaris independen akan memberikan penilaian secara transparan. Komisaris independen juga dapat mengontrol dan memberikan arahan kepada manajemen. Upaya yang dapat diberikan yaitu memberikan arahan dan masukan kepada manajemen ketika manajemen tidak melaksanakan aktivitas positif seperti pengungkapan CSR untuk memperoleh legitimasi dari masyarakat. Komisaris indepeden dapat mengendalikan kecurangan di setiap aktivitas perusahaan dengan tujuan menciptakan keseimbangan kepentingan berbagai pihak (Surya dan Yustivandana, 2006). Komisaris independen dapat mempengaruhi pengungkapan CSR karena komisaris berpegang pada prinsip keseimbangan untuk membuat perusahaan terus mempunyai keberlanjutan jangka panjang. Peningkatan yang terjadi pada komposisi dewan komisaris independen dalam struktur perusahaan maka perusahaan akan lebih memperdulikan pengungkapan CSRnya. Jadi, berdasarkan penjelasan di atas dapat ditarik hipotesis, yaitu:

$\mathrm{H}_{3}$ : Komposisi Dewan Komisaris Independen berpengaruh positif terhadap corporate social responsibility

\section{Kerangka Konseptual}

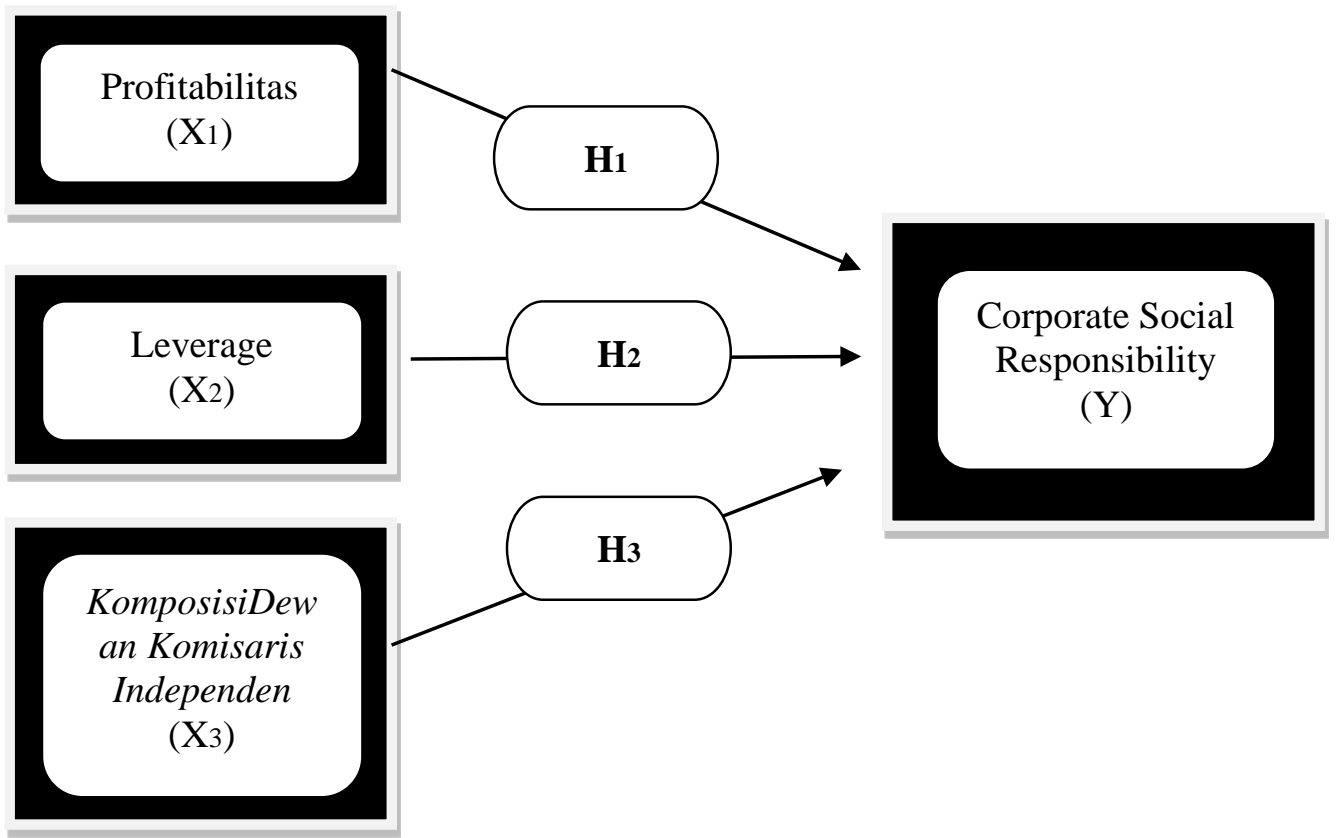

Gambar 1. Kerangka Konseptual 


\section{METODE PENELITIAN}

\section{Jenis Penelitian}

Jenis penelitian penelitian ini adalah penelitian kuantitatif karena menggunakan data berupa angka-angka. Penelitian ini menggunakan data sekunder yaitu data yang mengacu pada informasi yang diperoleh dari sumber yang telah ada. Data yang digunakan bersumber dari laporan keuangan tahunan perusahaan pertambangan yang terdapat di Indonesia Stock Exchange (IDX) (www.idx.co.id).

\section{Jenis dan Sumber Data}

Penelitian ini merupakan penelitian kuantitaif, sebab data-data yang digunakan diukur dalam suatu skala numerik (angka). Data yang digunakan dalam penelitian ini merupakan data sekunder. Data sekunder adalah data yang dikumpulkan oleh pihak lain (Kuncoro, 2003). Data sekunder yang dikumpulkan merupakan data cross-sectional dari perusahaan-perusahaan pertambangandan data time series untuk tahun 2014-2018. Sumber data sekunder yang digunakan dalam penelitian ini diperoleh dari situs resmi Bursa Efek Indonesia, yaitu www.idx.co.id.

\section{Populasi dan Sampel}

Populasi dari penelitian ini adalah seluruh perusahaan pertambangan yang terdaftar di Bursa Efek Indonesia periode 2014-2018. Sampel dari penilitian ini menggunakan salah satu teknik purposive sampling yaitu pertimbangan (judgment sampling). Pengambilan sampel betujuan dilakukan dengan mengambil sampel dari populasi berdasarkan kriteria atau pertimbangan tertentu.

\section{Tabel 1}

Kriteria Pemilihan Sampel

\begin{tabular}{clc}
\hline No & \multicolumn{1}{c}{ Kriteria } & Jumlah \\
\hline 1 & $\begin{array}{l}\text { Perusahaan pertambangan yang telah listing di Bursa Efek Indonesia } \\
\text { periode tahun 2014-2018. }\end{array}$ & 45 \\
2 & $\begin{array}{l}\text { Perusahaan yang tidak konsisten melaporkan annual report di BEI } \\
\text { tahun 2014-2018 }\end{array}$ & $(8)$ \\
3 & $\begin{array}{l}\text { Perusahaan yang menggunakan mata uang selain rupiah } \\
4\end{array}$ & $\begin{array}{c}\text { Perusahaan yang tidak mengungkapkan CSR secara berturut-turut } \\
\text { pada tahu 2014-2018 }\end{array}$ \\
& $\begin{array}{l}\text { Jumlah sampel penelitian per tahun } \\
\text { Jumlah sampel (10x5 periode penelitian) }\end{array}$ & $\mathbf{1 0}$ \\
& & $\mathbf{5 0}$ \\
\hline
\end{tabular}

Sumber : Data sekunder diolah (2019)

\section{Variabel Penelitian dan Pengukuran}

Variabel dependen dalam penelitian ini adalah corporate social responsibility yang diukur secara kuantitatif dengan memberikan skor 0 jika indikator kinerja tidak diungkapkan dan skor 1 diberikan jika indikator kinerja diungkapkan. Variabel independen yang digunakan dalam penelitian ini adalah profitabilitas, leverage dan komposisi dewan komisaris independen. Profitabilitas menggunakan pengukuran NPM (Net Profit Margin) yang dihitung dengan melakukan perbandingan antara laba bersih setelah pajak dengan penjualan bersih. Leverage menggunakan pengukuran DAR (Debt to Asset Ratio) yang dihitung dengan melakukan perbandingan antara total kewajiban dengan total asset, dan komposisi dewan komisaris 
independen dihitung dengan cara melakukan perbandingan antara jumlah dewan komisaris independen dengan jumlah dewan komisaris.

\section{Metode Analisis Data}

Analisis data pada penelitian ini diuji menggunakan analisis Regresi Linear Berganda dan dengan program SPSS 17.0. Tahapan yang digunakan dalam mengujji hipoteisi dalam penelitian ini adalah statistik deskriptif, uji asumsi klasik, dan uji hipotesis.

\section{HASIL DAN PEMBAHASAN \\ Statistik Deskriptif}

Tabel 2.

Statistik Deskriptif

\begin{tabular}{|c|c|c|c|c|c|}
\hline & $\mathrm{N}$ & Minimum & Maximum & Mean & Std. Deviation \\
\hline CSR & 50 & .0198 & .8614 & .182970 & .1890073 \\
\hline NPM & 50 & -28.2319 & .6953 & -1.691972 & 5.8112693 \\
\hline DAR & 50 & .2451 & .7808 & .475359 & .1274054 \\
\hline KDKI & 50 & .2500 & .7500 & .396000 & .0995773 \\
\hline Valid N (listwise) & 50 & & & & \\
\hline
\end{tabular}

Sumber : Output SPSS, olah data 2014-2018

Berdasarkan tabel 2 statistik deskripsi diketahui jumlah observasi pada penelitian ini adalah sebanyak 50. Variabel Y diketahui besarnya nilai mean adalah 0,1829 dengan standar deviasi 0,1890, nilai maksimum sebesar 0,8614 dan nilai minimum sebesar 0,0198. Variabel NPM diketahui besarnya nilai mean adalah -1,6919 dengan standar deviasinya 5,8112, nilai maksimum sebesar 0,6953 dan nilai minimum sebesar -28,2319. Variabel DAR diketahui besarnya nilai mean adalah 0,4753 dengan standar deviasinya 0,1274 , nilai maksimum sebesar 0,7808 dan nilai minimum sebesar 0,2451, dan untuk variabel KDKI diketahui mean adalah .3960 dengan standar deviasi 0,099, nilai maksimum sebesar 0,7500 dan nilai minimum sebesar 0,2500.

\section{Uji Asumsi Klasik}

\section{Uji Normalitas}

Pengujian normalitas bertujuan untuk mengetahui apakah distribusi pada data sudah mengikuti atau mendekati distribusi normal. Penelitian uji normalitas ini dilakukan dengan metode Kolmogorov-Smirnov dengan melihat tingkat signifikan 5\%. Menurut Ghozali (2011:160-165) uji Kolmogorov-Smirnov > 0,05 berarti residual dinyatakan terdistribusi normal, dan begitu juga sebaliknya.

Tabel 3

Uji Normalitas

\begin{tabular}{lcrrrrr}
\hline \multicolumn{2}{c}{ Kolmogorov-Smirnov } & \multicolumn{3}{c}{ Shapiro-Wilk } \\
& Statistic & Df & \multicolumn{1}{c}{ Sig. } & Statistic & Df & \multicolumn{1}{c}{ Sig. } \\
CSR & .213 & 50 & .000 & .748 & 50 & .000 \\
NPM & .409 & 50 & .000 & .360 & 50 & .000 \\
DAR & .133 & 50 & .027 & .955 & 50 & .053 \\
KDKI & .275 & 50 & .000 & .825 & 50 & .000 \\
a. Lilliefors Significance Correction & & & & \\
\hline
\end{tabular}




\section{Uji Multikolinieritas}

Uji multikonlinearitas bertujuan untuk menguji apakah model regresi ditemukan adaya korelasi antara variabel bebas (independen). Menurut Ghozali (2011:105) asumsi multikolinearitas menyatakan bawa variabel independen harus terbebas dari gejala mutikolinearitas. Gejala multikolinearitas merupakan gejala korelasi antar variabel independen.

Tabel 4. Uji Multikolinieritas

\begin{tabular}{|c|c|c|c|c|c|c|c|}
\hline \multirow[b]{2}{*}{ Model } & \multicolumn{2}{|c|}{ Unstandardized Coefficients } & \multicolumn{3}{|l|}{$\begin{array}{l}\text { Standardized } \\
\text { Coefficients }\end{array}$} & \multicolumn{2}{|c|}{ Collinearity Statistics } \\
\hline & B & Std. Error & Beta & $\mathrm{T}$ & Sig. & Tolerance & VIF \\
\hline 1 (Constant) & .573 & .169 & & 3.384 & .001 & & \\
\hline NPM & .004 & .005 & .116 & .812 & .421 & .918 & 1.089 \\
\hline DAR & -.401 & .216 & -.270 & -1.859 & .069 & .883 & 1.132 \\
\hline KDKI & -.487 & .274 & -.257 & -1.777 & .082 & .896 & 1.116 \\
\hline
\end{tabular}

Hasil uji multikolinearitas di atas dapat dilihat dari hasil perhitungan nilai tolerance dan VIF. Nilai tolerance untuk variabel Profitabilitas $\left(\mathrm{X}_{1}\right)$ sebesar 0,918 dengan nilai VIF sebesar 1,089. Variabel Leverage $\left(\mathrm{X}_{2}\right)$ nilai tolerance 0,883 dengan nilai VIF sebesar 1,132. Variabel Komposisi Dewan Komisaris Independen $\left(\mathrm{X}_{3}\right)$ nilai tolerance sebesar 0,896 dengan nilai VIF sebesar 1,116. Masing-masing variabel independen tersebut memiliki angka tolerance diatas 0,1 dan VIF $<10$. Jadi dapat disimpulkan bahwa tidak terdapat gejala multikolinearitas antar variabel independen.

\section{Uji Autokrelasi}

Tabel 5

Uji Autokorelasi

\begin{tabular}{|c|c|c|c|c|c|}
\hline \multicolumn{6}{|c|}{ Model Summaryb } \\
\hline Model & $\mathrm{R}$ & R Square & Adjusted R Square & $\begin{array}{l}\text { Std. Error of the } \\
\text { Estimate }\end{array}$ & Durbin-Watson \\
\hline 1 & $.374^{\mathrm{a}}$ & .140 & .083 & .1809556 & 1.256 \\
\hline \multicolumn{6}{|c|}{ a. Predictors: (Constant), KDKI, NPM, DAR } \\
\hline
\end{tabular}

Hasil uji autokorelasi pada tabel 11 menunjukkan bahwa nilai Durbin-Watson adalah 1,256 terletak diantara range -2 sampai +2 . Sehingga dapat disimpulkan bahwa tidak terjadi autokorelasi antara variabel pengganggu periode tertentu dengan periode sebelumnya.

\section{Uji Heterokedastisistas}

Uji heteroskedastisitas bertujuan menguji apakah dalam model regresi terjadi ketidaksamaan variance dari residual satu pengamatan ke pengamatan lain. Model regresi yang baik adalah hemoskedastistas atau tidak terjadi heterokedastisitas. Pengujian ini dapat dilakukan dengan berbagai uji yang dilakukan. Tabel di bawah ini merupakan hasil dari pengujian heteroskedastisitas dengan melihat grafik plot antara nilai prediksi variabel terikat (dependne) 
yaitu ZPRED dengan residualnya SRESID. Deteksi ada tidaknya pola tertentu pada grafik scatterplot antara SRESID dan ZPRED dimana sumbu Y adalah Y yang telah diprediksi, dan sumbu $\mathrm{X}$ adalah residual (Y prediksi - Y sesungguhnya) yang telah di studentized.

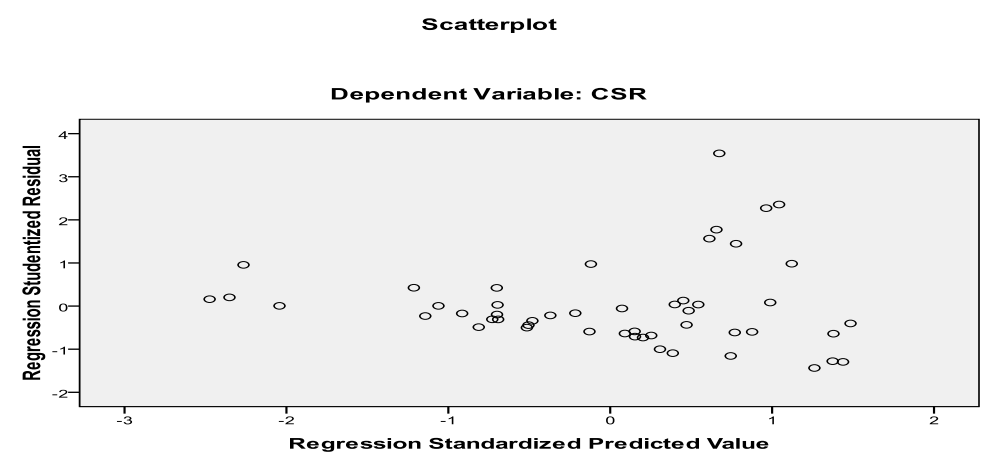

Gambar 2. Uji Heteroskedastisitas

Hasil uji heteroskeedastisitas berdasarkan table Scatterplot di atas dapat dilihat bahwa tidak ada pola yang jelas. Gambar tesebut tidak membentuk suatu pola tertentu. titik-titik yang ada menyebar secara acak serta tersebar baik diatas maupun dibawah angka 0 pada sumbuh Y dapat disimpulkan bahwa tidak terjadi heteroskedastisitas pada model regresi dan layak untuk diteliti.

Model Pengujian Hipotesis Penelitian Analisis Regresi Linear Berganda

Tabel 7. Uji Regresi Berganda

\begin{tabular}{|c|c|c|c|c|c|}
\hline \multirow[b]{2}{*}{ Model } & \multicolumn{2}{|c|}{ Unstandardized Coefficients } & \multicolumn{3}{|l|}{$\begin{array}{l}\text { Standardized } \\
\text { Coefficients }\end{array}$} \\
\hline & B & Std. Error & Beta & $\mathrm{t}$ & Sig. \\
\hline 1 (Constant) & .573 & .169 & & 3.384 & .001 \\
\hline NPM & .004 & .005 & .116 & .812 & .421 \\
\hline DAR & -.401 & .216 & -.270 & -1.859 & .069 \\
\hline KDKI & -.487 & .274 & -.257 & -1.777 & 082 \\
\hline
\end{tabular}

Dari pengolahan data statistik di atas maka diperoleh persamaan regresi linear berganda sebagai berikut:

$$
Y=0,573+0,004 X_{1}-0,004 X_{2}-0,487 X_{3}+e
$$

\section{Uji Koefisien Determinasi (Adjusted $\mathbf{R}^{2}$ )}

Mengetahui kontribusi dari variabel bebas terhadap variabel terikat dapat dilihat dari adjusted $R$ square-nya. Koefisien determinasi pada intinya mengukur seberapa jauh kemampuan model 
dalam menjelaskan variasi variabel terikat. Hasil uji koefisien determinasi seperti terlihat pada table di bawah ini:

Tabel 8. Koefisien Determinasi

\begin{tabular}{|c|c|c|c|c|c|}
\hline Model & $\mathrm{R}$ & R Square & Adjusted R Square & $\begin{array}{l}\text { Std. Error of the } \\
\text { Estimate }\end{array}$ & Durbin-Watson \\
\hline 1 & $.374^{\mathrm{a}}$ & .140 & .083 & .1809556 & 1.256 \\
\hline \multicolumn{6}{|c|}{ a. Predictors: (Constant), KDKI, NPM, DAR } \\
\hline \multicolumn{6}{|c|}{$\begin{array}{l}\text { b. Dependent Variable: CSR } \\
\text { Sumber Data: Olahan Data SPSS } 17 \text { tahun } 2018\end{array}$} \\
\hline
\end{tabular}

Hasil pengujian dari tabel diatas menunjukkan nilai Adjusted $R$ Square sebesar 0,083. Hal ini berarti $8,3 \%$ nilai pengungkapan corporate social responsibility dipengaruhi oleh ke-tiga variabel independen yaitu profitabilitas, leverage, dan komposisi dewan komisaris independen. Sedangkan $91,7 \%$ di pengaruhi oleh variabel lain yang tidak diteliti.

\section{Uji F}

Uji F dilakukan untuk menguji apakah secara serentak atau bersama-sama variabel independen mampu menjelaskan variabel dependen secara baik atau untuk menguji apakah model yang digunakan diterima atau tidak. Hasil pengujian ini dapat dilihat pada tabel di bawah ini:

Tabel 9. Uji F

\begin{tabular}{|c|c|c|c|c|c|c|}
\hline \multicolumn{2}{|c|}{ Model } & Sum of Squares & Df & Mean Square & $\mathrm{F}$ & Sig. \\
\hline \multirow[t]{3}{*}{1} & Regression & .244 & 3 & .081 & 2.486 & $.072^{\mathrm{a}}$ \\
\hline & Residual & 1.506 & 46 & .033 & & \\
\hline & Total & 1.750 & 49 & & & \\
\hline \multicolumn{7}{|c|}{ a. Predictors: (Constant), KDKI, NPM, DAR } \\
\hline \multicolumn{7}{|c|}{ b. Dependent Variable: CSR } \\
\hline
\end{tabular}

Sumber Data : Data Olahan SPSS 17 tahun 2018

Hasil pengolahan data, dapat dilihat bahwa F hitung yaitu 2,486 dengan signifikan yaitu 0,072 < 0,05 . Karena nilai signifikan kecil dari 0,05 maka model regresi yang digunakan sudah benar atau diterima, sehingga dapat digunakan untuk memprediksi variabel-variabel penelitian. Berarti profitabilitas, leverage, dan komposisi dewan komisaris independen berpengaruh secara bersama-sama terhadap pengungkapan corporate social responsibility.

\section{Uji Hipotesis (Ujit)}

Uji t (t-test) dilakukan untuk menguji apakah secara terpisah variabel independen mampu menjelaskan variabel dependen secara baik. 


\section{Tabel 10. Uji t}

\begin{tabular}{|c|c|c|c|c|c|}
\hline \multirow[b]{2}{*}{ Model } & \multicolumn{2}{|c|}{$\begin{array}{l}\text { Unstandardized } \\
\text { Coefficients }\end{array}$} & \multicolumn{3}{|l|}{$\begin{array}{l}\text { Standardized } \\
\text { Coefficients }\end{array}$} \\
\hline & B & Std. Error & Beta & $\mathrm{t}$ & Sig. \\
\hline 1 (Constant) & .573 & .169 & & 3.384 & .001 \\
\hline NPM & .004 & .005 & .116 & .812 & .421 \\
\hline DAR & -.401 & .216 & -.270 & -1.859 & .069 \\
\hline KDKI & -.487 & .274 & -.257 & -1.777 & .082 \\
\hline
\end{tabular}

a. Dependent Variable: CSR

Sumber Data : Olahan Data SPSS 17 tahun 2018

Berdasarkan tabel diatas maka dapat dilihat pengaruh variabel bebas terhadap variabel terikat secara parsial sebagai berikut:

1. Hipotesis pertama dalam penelitian ini adalah profitabilitas $\left(\mathrm{X}_{1}\right)$. Tabel 12 menunjukkan bahwa koefisien regresi profitabilitas bernilai positif sebesar 0,004 dengan tingkat signifikansi 0,421 dimana tingkat signifikansi tersebut lebih besar dari $\alpha$, yakni sig. $0,421>\alpha(0,05)$, berdasarkan hasil tersebut maka profitabilitas berpengaruh positif dan tidak signifikan terhadap pengungkapan corporate social responsibility. Penjelasan tersebut dapat disimpulkan bahwa hipotesis pertama $\left(\mathbf{H}_{1}\right)$ ditolak.

2. Hipotesis kedua dalam penelitian ini adalah leverage $\left(\mathrm{X}_{2}\right)$. Tabel 12 menunjukkan bahwa koefisien leverage bernilai negatif sebesar 0,401 dengan tingkat signifikansi 0,069 dimana tingkat signifikansi tersebut lebih besar dari $\alpha$, yakni sig. 0,401> $>(0,05)$, berdasarkan hasil tersebut leverage berpengaruh negatif dan tidak signifikan terhadap pengungkapan corporate social responsibility. Penjelasan tersebut dapat disimpulkan bahwa hipotesis kedua (H2) ditolak.

3. Hipotesis ketiga dalam penelitian ini adalah komposisi dewan komisaris independen $\left(\mathrm{X}_{3}\right)$. Tabel 12 menunjukkan bahwa koefisien komposisi dewan komisaris independen bernilai negarif sebesar 0,487 dengan tingkat signifikansi 0,082 dimana tingkat signifikansi lebih besar dari $\alpha$, yakni sig. 0,082 $>\alpha(0,05)$, berdasarkan hasil tersebut komposisi dewan komisaris independen berpengaruh negatif dan tidak signifikan terhadap pengungkapan corporate social responsibility. Penjelasan tersebut dapat disimpulkan bahwa hipotesis ketiga (H3) ditolak.

Tabel 11

Ringkasan Hasil Penelitian

\begin{tabular}{cccc}
\hline \multicolumn{2}{c}{ Hipotesis } & p-value & Hasil \\
\hline H1 & Profitabilitas berpengaruh positif terhadap corporate & $0,421>$ & ditolak \\
& social responsibility & 0,05 & \\
H2 & Leverage berpengaruh negatif terhadap corporate & $0.401<$ & Ditolak \\
& social responsibility & 0,05 & \\
$\mathbf{H 3}$ komposisi Dewan Komisaris Independen & $0.487<$ & Ditolak \\
& berpengaruh negatif terhadap corporate social & 0,05 & \\
$\quad$ responsibility & & \\
Sumber: Data diolah (2020) & &
\end{tabular}




\section{Pembahasan}

Pengaruh Profitabilitas terhadap Pengungkapan Corporate Social Responsibility.

Hasil hipotesis pertama dalam penelitian yaitu profitabilitas berpengaruh positif tetapi tidak signifikan dengan menunjukkan bahwa koefisien regresi profitabilitas bernilai positif sebesar 0,004 dengan tingkat signifikansi 0,421 dimana tingkat signifikansi tersebut lebih besar dari $\alpha$, yakni sig. $0,421>\alpha(0,05)$, hasil tersebut dapat disimpulkan bahwa hipotesis pertama tidak terdukung atau $\mathrm{H}_{1}$ ditolak.

Alasan penolakan atas hipotesis yang diajukan adalah karena laba yang dimiliki perusahaan diprioritaskan untuk kepentingan operasional, sehingga pemanfaatan untuk aktivitas sosial lebih sedikit. Manajemen merasa tidak perlu memberikan pengungkapan tentang keberhasilannya kepada publik, karena hal tersebut tidak mempunyai pengaruh terhadap posisinya dan kompensasi yang diperolehnya, ini dapat terjadi karena penentuan posisi dan kompensasi manajemen pada perusahaan publik di Indonesia lebih banyak ditentukan oleh pemegang saham mayoritas yang pada umumnya adalah pemilik perusahaan.

Perusahaan mengganggap dengan mengungkapkan CSR secara luas akan mengurangi laba yang di miliki. Karena semakin luas pengungkapan maka biaya yang dikeluarkan juga semakin banyak. Perusahaan yang memiliki tingkat profitabilitas yang tinggi cenderung akan lebih mengutamakan kepentingan pihak investor untuk tetap mempertahankan investor lama dan dapat menarik minat investor baru yang hanya memprioritaskan laba semata. Perusahaan yang memiliki tingkat profitabilias tinggi sebaiknya tetap mengungkapkan corporate social responsibility karena persepsi atau anggapan bahwa aktivitas CSR bukanlah aktivitas yang merugikan dan tidak bermanfaat bagi keberlangsungan perusahaan.

Menurut Solomon dan Hansen (1985) dalam Mc Guire et. Al (1985), dengan CSP (corporate social performance) yang baik mampu meningkatkan goodwill karyawan dan konsumen, sehingga perusahaan tersebut menghadapi masalah dengan tenaga kerja yang lebih sedikit, lalu konsumen akan lebih setia kepada produk perusahaan. Peningkatan hubungan dengan pihak bank, investor, pemerintah, dan masyarakat dapat memberikan peningkatan ekonomi.

Hasil penelitian ini tidak sejalan dengan penelitian Rindawati \& Asyik (2015) dan Felicia \& Rasmini (2015) yang menyatakan bahwa profitabilitas berpengaruh signifikan terhadap pengungkapan CSR. Penelitian ini mendukung penelitian Krisna \& Suhardianto (2016) yang menyatakan bahwa profitabilitas tidak berpengaruh signifikan terhadap pengungkapan CSR.

\section{Pengaruh Leverage terhadap Pengungkapan Corporate Social Responsibility.}

Hasil hipotesis kedua dalam penelitian yaitu leverage berpengaruh negatif tetapi tidak signifikan dengan menunjukkan bahwa koefisien regresi leverage bernilai negatif sebesar 0,401 dengan tingkat signifikansi 0,069 dimana tingkat signifikansi tersebut lebih besar dari $\alpha$, yakni sig. 0,069 $>\alpha(0,05)$, hasil tersebut dapat disimpulkan bahwa hipotesis kedua tidak terdukung atau $\mathrm{H}_{2}$ ditolak.

Alasan penolakan atas hipotesis yang diajukan karena tujuan utama perusahaan adalah memaksimalkan keuntungan pemegang saham yang diwujudkan dengan meningkatkan laba perusahan. Perusaahaan akan berupaya untuk meningkatkan efisiensi biaya operasional guna meningkatkan laba. Laba yang dilaporkan tinggi maka manejer harus mengurangi biaya-biaya (termasuk biaya untuk mengungkapkan informasi sosial). 
Hasil penelitian ini, leverage mempunyai arah hubungan negatif. Menunjukkan adanya hubungan yang berbanding terbalik antara leverage dengan tingkat pengungkapan tanggung jawab sosial. Semakin besar leverage suatu perusahaan, maka tingkat pengungkapan tanggung jawab sosial perusahaan akan semakin rendah, begitupun sebaliknya semakin kecil leverage suatu perusahaan, maka tingkat pengungkapan tanggung jawab sosial perusahaan akan semakin rendah.

Hasil ini bertentangan dengan teori agency yang menyatakan semakin besar proporsi utang suatu perusahaan, maka semakin luas pula informasi yang dipaparkan, Perusahaan dengan tingkat leverage rendah maka besar kemungkinannya bagi perusahaan untuk memprioritaskan pengungkapan CSR karena perusahaan hanya ingin meningkatkan citra perusahan dimata debtholder untuk tetap memberikan modal pinjaman yang nantinya akan digunakan perusahan dalam kegiatan operasionalnya. Hasil penelitian ini tidak sejalan dengan penelitian Nur \& Priantinah (2012) dan Rachman \& Nopiyanti (2015) yang menyatakan bahwa leverage mempunyai pengaruh signifikan terhadap pengungkapan CSR. Penelitian ini mendukung penelitian Prakarsa \& Astika (2017) yang menyatakan leverage tidak mempuyai pengaruh terhadap pengungkapan CSR. Alasan penolakan hipotesa yang diajukan mungkin disebabkan karena informasi yang ada dalam laporan tahunan tidak banyak memberikan kontribusi bagi aktivitas CSR yang dilakukan perusahaan.

\section{Pengaruh Komposisi Dewan Komisaris Independen terhadap Pengungkapan Corporate Social Responsibility}

Hasil hipotesis ketiga dalam penelitian yaitu komposisi dewan komisaris independen berpengaruh negatif tetapi tidak signifikan dengan menunjukkan bahwa koefisien regresi komposisi dewan komisaris independen bernilai negatif sebesar 0,487 dengan tingkat signifikansi 0,082 dimana tingkat signifikansi tersebut lebih besar dari $\alpha$, yakni sig. 0,082 $>\alpha$ $(0,05)$, hasil tersebut dapat disimpulkan bahwa hipotesis ketiga tidak terdukung atau $\mathbf{H}_{3}$ ditolak.

Hasil Penelitian ini tidak berpengaruh disebabkan karena dewan komisaris independen yang dimiliki oleh perusahaan pertambangan yang menjadi sampel dalam penelitian ini tidak dapat menjalankan peran dan fungsinya. Keberadaan dewan komisaris independen tidak dapat memberikan kontrol dan monitoring bagi manajemen dalam operasional perusahaan, termasuk dalam pelaksanaan dan pengungkapan aktivitas tanggung jawab sosial (Susanti \& Riharjo, 2013). Komposisi dewan komisaris independen tidak berpengaruh terhadap pengungkapan CSR sepertinya dikarenakan batas minimum dewan komisaris independen hanya sebesar $30 \%$, sehingga pengaruh yang diberikan oleh dewan komisaris independen belum cukup tinggi untuk mempengaruhi dewan komisaris, dan hal ini dapat dilihat dari rata-rata tingkat pengungkapan CSR yang dilakukan perusahaan pertambangan yang menjadi sampel dalam penelitian ini yang tidak mencapai 50\% padahal memiliki dewan komisaris yang mencapai $30 \%$.

Dewan komisaris merupakan wakil shareholders yang berfungsi mengawasi pengelolaan perusahaan yang dilakukan oleh manajemen, maka dewan komisaris independen akan membuat kebijakan menggunakan laba perusahaan untuk aktivitas operasional perusahaan yang lebih menguntungkan dari pada melakukan aktivitas sosial. Tugas dari dewan komisaris independen adalah sebagai pengawas dan pemberi arahan namun yang mengambil keputusan di suatu perusahaan adalah pihak manajemen, dan kemungkinan pihak manajemen lebih memprioritaskan untuk meningkatkan laba perusahaan dari pada harus mengungkapkan laporan CSR yang lebih lengkap yang dapat mengurangi laba perusahan. 
Hasil penelitian komposisi dewan komisaris independen tidak berpengaruh terhadap Pengungkapan CSR. Hasil penelitian ini tidak sejalan dengan penelitian Nurkhin (2010) yang menyatakan komposisi dewan komisaris independen berpengaruh signifikan terhadap pengungkapan CSR. Penelitian ini mendukung penelitian Sari Lian Permata (2014) menyatakan komposisi dewan komisaris independen tidak berpengaruh signifikan terhadap pengungkapan CSR.

\section{KESIMPULAN, KETERBATASAN, DAN SARAN \\ Kesimpulan}

Hasil penelitian adalah sebagai berikut:

1. Profitabilitas berpengaruh positif dan tidak signifikan terhadap pengungkapan CSR pada perusahaan pertambangan yang terdafatar di BEI selama tahun 2014-2018.

2. Leverage berpengaruh negatif dan tidak signifikan terhadap pengungkapan CSR pada perusahaan pertambangan yang terdafatar di BEI selama tahun 2014-2018.

3. Komposisi dewan komisaris independen berpengaruh negatif dan tidak signifikan terhadap pengungkapan CSR pada perusahaan pertambangan yang terdafatar di BEI selama tahun 2014-2018.

\section{Keterbatasan}

Meskipun peneliti telah berusaha merancang dan mengembangkan penelitian sedemikian rupa, namun masih terdapat beberapa keterbatasan dalam penelitian yaitu :

1. Sampel untuk penelitian ini hanya dilakukan pada perusahaan pertambangan, sehingga hasil penelitian ini tidak dapat digunakan sebagai dasar generalisasi.

2. Peneliti menggunakan indikator GRI-G4 dan GRI-MM dalam menghitung pengungkapan CSR yang mana hanya sebagian perusahaan yang sudah menerapkan GRI-MM sesuai dengan indikator CSR khusus industri pertambangan.

3. Adjusted $\mathrm{R}^{2}$ pada penelitian ini sebesar $8,3 \%$. Hal ini menunjukkan bahwa masih banyak terdapat faktor lain di luar variabel independen pada penelitian ini yang dapat menjelaskan variabel dependen misalnya karakteristik perusahaan, manajemen laba, struktur kepemilikan dan lainnya.

4. Masih sedikit perusahaan go publik yang membuat laporan berkelanjutan (sustainability report).

\section{Saran}

Berdasarkan hasil penelitian yang telah diperoleh, penulis dapat mengemukakan beberapa saran sebagai berikut :

1. Hasil pengungkapan tanggung jawab sosial perusahaan sektor pertambangan yang cenderung tidak sama dalam setiap tahunnya, sebaiknya perusahaan tetap meningkatkan pengungkapan tanggung jawab sosial yaitu sesuai dengan pedoman yang telah ditetapkan GRI-G4 dan GRI Mining and Metal Sector Supplement (khusus industri pertambangan) sebagai bentuk pemenuhan informasi terhadap berbagai pihak atas aktivitas perusahaan.

2. Peneliti selanjutnya apabila tertarik untuk melakukan penelitian yang serupa dengan penelitian ini sebaiknya tidak hanya menggunakan variabel profitabilitas, leverage dan komposisi dewan komisaris independen tetapi juga dapat menambah karakteristik perusahaan, manajemen laba, struktur kepemilikan dan lainnya yang turut berpengaruh serta dapat 
mencoba meneliti pada jenis perusahaan selain perusahaan pertambangan dan menambah rentang waktu yang dijadikan penelitian.

3. Peneliti selanjutnya menggunakan sampel perusahaan yang mengeluarkan laporan berkelanjutan (suistainable report) agar dapat melihat pengaruh variabel CSR.

\section{DAFTAR PUSTAKA}

Amran, Azlan dan Devi S. Susela. (2008). The Impact Of Government And Foreign Affiliate Influence On Corporate Social Reporting (The Case Of Malaysia)". Accounting, Auditing and Accountability Journal, 23(4), 386-404.

Anggraini, Retno. (2006). Pengungkapan Informasi Sosial dan Faktor-Faktor yang Mempengaruhi Pengungkapan Informasi Sosial dalam Laporan Keuangan Tahunan. Simposium Nasional Akuntansi IX. 30-45.

Anugrah, Rita., Rolland Hutabarat., dan Faradilla, W. (2010). Pengaruh Ukuran Perusahaan, Leverage dan Profitabilitas terhadap Pengungkapan Tanggung Jawab Sosial Perusahaan pada Perusahaan Manufaktur yang Listing di BEI, Jurnal Ekonomi. 18.

Darwin, Ali. (2006). Corporate Social Responsibility. Jakarta: EBAR.

Evi, Muthia., Zuraida., dan Devi, Andriani. (2011). Pengaruh Ukuran Perusahaan, Profitabilitas dan Ukuran Dewan Komisaris terhadap Pengungkapan Corporate Social Responsibility pada Perusahaan Manufaktur yang Terdaftar pada BEI. Jurnal Telaah Riset Akuntansi. 4(2).

Febrina, dan Agung, Suaryana. (2011). Faktor-faktor yang mempengaruhi kebijakan pengungkapan tanggung jawab sosial dan lingkungan pada perusahaan manufaktur di bursa efek Indonesia. Simposium Nasional Akuntansi XIV. Aceh. 1-26.

Felicia, M dan Rasmini, K. N. (2015). Faktor-faktor yang mempengaruhi Pengungkapan Corporate Social Responsibility pada Perusahaan yang terdaftar di BEI. E-Jurnal Akuntansi Universitas Udayana: 143-153. ISSN:2302-8556.

Ghozali, Imam. (2011). Aplikasi Analisis Multivariate dengan Program SPSS. Semarang: Badan Penerbit Universitas Diponegoro.

Kasmir. (2008). Analisis Laporan Keuangan, Edisi Ketiga. Jakarta: Rajawali Pers.

Komalasari, Dessy dan Anna, Yane Devi. (2014). Pengaruh Mekanisme Corporate Governance, Ukuran Perusahaan dan Profitabilitas Perusahaan terhadap Corporate Social Responsibility (Studi pada Perusahaan Perbankan yang Listing di Bursa Efek Indonesia Tahun 2008-2011. Jurnal Akuntansi Institut Manajemen Telkom.

Krisna, Aditya Dharmawan dan Suhardianto, Novrys. (2016). Faktor-Faktor yang Mempengaruhi Pengungkapan Tanggung Jawab Sosial. Jurnal Akuntansi dan Keuangan. 18(2).

Nur, M dan Priantinah, D. (2012). Analisis Faktor-Faktor yang Memengaruhi Pengungkapan Corporate Social Responsibility di Indonesia (Studi Empiris pada Perusahaan Berkategori High Profile yang Listing di Bursa Efek Indonesia). Jurnal Nominal. 1(1).

Nurkhin, Ahmad. 2009. Corporate Governance dan Profitabilitas Pengaruhnya terhadap Pengungkapan Tanggung Jawab Sosial Perusahaan (Studi Empiris pada Perusahaan yang terdaftar di Bursa Efek Indonesia). Jurnal Magister Akuntansi. Universitas Diponegoro.

Oktavila \& Erinos, N.R. (2019). Pengaruh Kapitalisasi Pasar dan Good Corporate Governance terhadap Pengungkapan Corporate Social Responsibility (Studi Empiris pada Perusahaan Manufaktur yang Terdaftar di Bursa Efek Indonesia Tahun 2015-2017). Jurnal Eksplorasi 
Akuntansi, 1(3), Seri C, 1184-1199.

Oktaviana dan Rustyaningsih. 2013. Karakteristik Perusahaan dan Pengungkapan Tanggung Jawab Sosial Pada Perusahaan Manufaktur Go Publik. Jurnal Riset Manajemen dan Akuntansi. 1(1).

Prakasa, Sila dan Astika, Putra I.B. 2017. Pengaruh Leverage, Profitabilitas dan Kepemilikan Manajemen pada Corporate Social Responsibility Disclosure Perusahaan Pertambangan. E-Jurnal Akuntasni Universitas Udayana. Vol.18. hlm 189-215. ISSN: 2302-8556.

Rachman, A.H dan Nopiyanti, A. 2015. Pengaruh Profitabilitas, Leverage, dan Ukuran Perusahaan terhadap Pengungkapan Corporate Social Responsibility (CSR). Jurnal UPN Jakarta Selatan. 18(2).

Rindawati, M.W dan Asyik, N.F. (2015). Pengaruh Profitabilitas, Ukuran Perusahaan, Leverage, dan Kepemilikan Saham Publik terhadap Pengungkapan Corporate Social Responsibility (CSR). Jurnal Ilmu dan Riset Akuntansi. 4(6).

Robiah, A.M dan Erawati, T. (2017). Pengaruh Leverage, Size, dan Kepemilikan Manjemen terhadap Corporate Social Diasclosure. Jurnal UST Jogja. 1, 39-48.

Sari, Lian Permata. (2014). Pengaruh Profitabilitas, Proporsi Dewan Komisaris independen dan Kepemilikan Saham Asing terhadap Pengungkapan Corporate Social Responsibility. (Studi Empiris pada Perusahaan yang tercatat di Bursa Efek Jakarta). Jurnal Akuntansi.

Scott, W.R. 2000. Financial Accounting Theory. Edisi ke-3. Pretice Hall Canada Inc.

Sembiring, Eddy Rismanda. (2005). Karakteristik Perusahaan dan Pengungkapan Tanggung Jawab Sosial. (Studi Empiris pada Perusahaan yang Tercatat di Bursa Efek Jakarta). Simposium Nasional Akuntansi VII Solo.

Surya, Indra dan Yustiavandana, Ivan. (2006). Penerapan Good Corporate Governnace Mengesampingkan Hak-hak Istimewa Demi Kelangsungan Usaha. Jakarta: Prenda Media Group.

Undang-Undang Republik Indonesia Nomor 40 Tahun 2007 tentang Perseroan Terbatas. 2008. Jakarta.

Untung, Budi. (2014). CSR dalam Dunia Bisnis. Yogyakarta.

Yusra, Nelhendra. (2009). Faktor-Faktor yang Mempengaruhi Pengungkapan Corporate Social Responsibility pada Perusahaan Manufaktur yang Terdaftar pada BEI. Jurnal Universitas Andalas.

www.idx.co.id. 